\title{
Enhancing Vocational Teachers' Professionalism in Teaching Government Accounting
}

\author{
Vita Fitria Sari ${ }^{*}$,Dewi Pebriyani ${ }^{2}$, Mayar Afriyenti ${ }^{3}$ \\ 1,2,3 Universitas Negeri Padang, Padang, Indonesia, \\ "Corresponding author.Email: vitafitriasari@gmail.com
}

\begin{abstract}
The implementation of the 2013 curriculum in Vocational High Schools has introduced the field of government accounting in the vocational curriculum with the subject "accounting practicum for government institutions / agencies". The 2013 curriculum introduces the terms remedial and enrichment in the learning process. Enrichment is an activity given to fast group students so that they can develop their potential optimally by utilizing the remaining time they have. The challenge in the future of professionalism faced by teachers is how teachers can develop the existing potential for students who can quickly understand the material that has been given considering that the field of government accounting is a new field of accounting for vocational accounting teachers. This research use capacity building and workshop in order to enhance vocational accounting teachers' professionalism in teaching government accounting by presenting local government financial statement for level head office and consolidation of local government financial statement. This research categorized as pre-experimental (nondesign) by the method of the one group pretest - posttest design. The results showed that there are differences on vocational accounting teachers' understanding in presenting local government financial statement for level head office and consolidation of local government financial statement before and after got capacity building and workshop.
\end{abstract}

Keywords: capacity building, government accounting, professionalism, vocational accounting teachers', workshop

\section{INTRODUCTION}

The implementation of the 2013 curriculum in Vocational High Schools in the major of accounting and financial institutions has introduced the field of government accounting in vocational schools curriculum's with the subject "accounting practicum for government institutions / agencies". The subject of "accounting practicum for government institutions / agencies" began to be taught in 2018 for class XI and then continued in 2019 for class XII. This subject "accounting practicum for government institutions / agencies" contains two main subjects, which are preparation of regional government financial reports; especially for local government agencies (branch office) taught in class XI and the preparation of village financial reports taught in class XII. Although government accounting has only just begun to be integrated in Vocational High School curriculum in 2013 and began to be taught in classrooms in 2018, this is no longer considered a new thing for vocational accounting teachers.
The 2013 curriculum introduces the terms remedial and enrichment in the learning process. Remedial aims to help students who have difficulty mastering the competencies that have been carried out in order to achieve better learning outcomes. Meanwhile, enrichment is an activity given to students in quick groups so that they can develop their potential optimally by utilizing the remaining time they have. In general, the purpose of enrichment is to increase understanding and insight into the material that is being or has been studied and so that students can learn optimally both in terms of utilizing their abilities and the acquisition of learning outcomes [1] . Students who are very fast in learning can master the learning material given faster than their classmates. Enrichment teaching can be carried out well, if it is planned, implemented and evaluated properly, besides that support from various parties is needed. There are several factors that must be considered in enrichment teaching, namely, students, teachers, the media in implementation, and the timing of enrichment teaching. 
Therefore, in the 2013 curriculum subject teachers have an important role in helping and striving for the achievement of learning completeness and educational goals. Each student has a unique personality and different learning styles. Subject teachers are expected not only to teach but also to understand how different each student is in their class. The intensity of meeting and meeting face to face frequently, of course, makes it easier for subject teachers to understand the differences of each student. This of course is closely related to teacher professionalism.

During the last 2 years the material given in the subject of "accounting practicum for government institutions / agencies" to vocational school students was limited to accounting at the local government agencies (branch office). In accordance with the lesson plan for the subject "practicum accounting for government institutions / agencies", there is topic accounting for financing that has not been taught so far. The Head of the MGMP Team for Vocational Accounting School in West Sumatra Province stated that so far the material provided in training related to government accounting had never explained the material because accounting for financing in government is in the scope of the head office, namely the PPKD function. Therefore, the team leader MGMP Team for Vocational Accounting School in West Sumatra Province really wants to explore about accounting for context head office in local government to the consolidation of government financial reports as material enrichment for the subject of "government agency / agency accounting practicum". According to [1], enrichment aims to increase students' understanding and insight into the material being or has been studied so that students can learn optimally.

However, in reality there are still many teachers who do not receive adequate training before being assigned to teach subjects, especially for new subjects. This causes teachers to be sometimes reluctant to accept additional assignments or new subjects. Increasing teacher professionalism is needed in order to improve the quality of learning. Increasing teachers' understanding of government accounting material, especially by understanding accounting for head office and consolidating local government financial reports is one form of teacher professionalism to develop subject matter "accounting practicum for government institutions / agencies". This, of course, is expected to develop student potential quickly, so that teachers can take advantage of the remaining time they have by providing accounting for head office and consolidating local government financial reports material. In addition, increasing students' understanding of government accounting can expand internship opportunities for vocational students. Starting in 2019, SMK students have started to intern at government agencies such as sub-districts and offices (branch offices), by mastering accounting for head office in local government vocational accounting students' can be given the opportunity to intern at PPKD (head office).

Efforts to improve teacher professionalism are necessary as an effort to improve the quality of learning. [2] found that teacher professionalism has a significant effect on the learning success of vocational high school students in the city of Padang. Therefore, teachers can take various ways in order to improve teacher professionalism. [3] states that teachers can attend workshops or conferences as a way of developing teacher professionalism. Workshops and conferences allow large numbers of teachers to come together to learn from each other and share materials and update technology skills. This is in line with [4] state that forms of professional development that can be held for teachers are training and workshops with general or specific objectives.

This research will try to use capacity building and workshop as treatment in in order to improve vocational accounting teachers' professionalism in teaching government accounting. This paper consist of 4 parts which are introduction, research methods, results and discussion, and the last part conclusions.

\section{METHODS}

This research categorized as pre-experimental (nondesign) by the method of the one group pretest posttest design. Variable treatment in this study are capacity building and workshop in presenting local government financial statement for level head office and consolidation of local government financial statement. The following steps in reserach are:

1. determine the problem of this research.

The need for material enrichment in subject "accounting practicum for government institutions / agencies" for vocational accounting curriculums'.

2. selection of the subject of experiments.

The subject in this research are government accounting teachers' from vocational accounting schools in West Sumatera Province. There are 34 participants join in this research.

\section{Development of instrument}

The instruments used in this research was capacity building and workshop in presenting local government financial statement for level head office and consolidation of local government financial statement.

\section{Selection of research design.}

This research design as pre-experimental (nondesign) by the method of the one group pretest posttest design 
5. Execution of the procedure.

The execution procedure in this research are use capacity building and workshop in presenting local government financial statement for level head office and consolidation of local government financial statement. This treatment implemented for 2 days. At the beginning, researchers will conduct a pre-test about the concept of presenting local government financial statement for level head office and consolidation of local government financial statement. Then, vocational accounting teachers' will get capacity building and workshop in presenting local government financial statement for head office and consolidation of local government financial statement. At the end of the treatment, researchers will conduct post-test in order to identified the effect of using capacity building and workshop in presenting local government financial statement for head office and consolidation of local government financial statement.

6. data analysis.

To see the effects of capacity building and workshop in presenting local government financial statement for head office and consolidation of local government financial statement, then data will be analysis with independent sample $t$ test, to see if there is a difference on understanding in presenting local government financial statement for head office and consolidation of local government financial statement before and after got capacity building and workshop. The hypothesis of this study is:
Ha: there is a difference on vocational accounting teachers' understanding in presenting local government financial statement for head office and consolidation of local government financial statement before and after got capacity building and workshop.

\section{RESULTS AND DISCUSSIONS}

Table.1 Descriptions of Participants

\begin{tabular}{|l|l|c|}
\hline Gender & Male & $8.70 \%$ \\
& Female & $91.30 \%$ \\
\hline Teaching & $0 \leq 5$ & $13.04 \%$ \\
experience & $\geq 5-10$ & $28.26 \%$ \\
& $\geq 10-15$ & $30.43 \%$ \\
& $>15$ & $28.26 \%$ \\
\hline
\end{tabular}

Based on table 2, it can be seen that the field of government accounting is not a new for accounting teachers in West Sumatra Province; this can be seen from the answer to the first question where there were 22 participants or $64.71 \%$ who had taught subjects related to government accounting topics. While the remaining 12 participants or $35.29 \%$ never taught, subjects related to government accounting topics. Most of the participants had attended training related to government accounting topics, which are 27 participants or $79.41 \%$ while the other 7 participants or $20.59 \%$ had never attended training on government accounting topics.

Table 2. Knowledge of Government Accounting

\begin{tabular}{|c|c|c|c|c|}
\hline \multirow{2}{*}{ Question } & \multicolumn{2}{|c|}{ Ever } & \multicolumn{2}{|c|}{ Never } \\
\hline & Amount & $\%$ & amount & $\%$ \\
\hline Has taught government accounting subjects & 22 & $64,71 \%$ & 12 & $35,29 \%$ \\
\hline \multirow[t]{3}{*}{ Have attended training related to government accounting } & 27 & $79,41 \%$ & 7 & $20,59 \%$ \\
\hline & \multicolumn{2}{|c|}{ Yes } & \multicolumn{2}{|c|}{ No } \\
\hline & Amount & $\%$ & amount & $\%$ \\
\hline $\begin{array}{l}\text { Have books / references related to government accounting } \\
\text { material }\end{array}$ & 26 & $76,47 \%$ & 8 & $23,53 \%$ \\
\hline $\begin{array}{l}\text { Has teaching materials for the subject "practicum accounting } \\
\text { for government institutions / agencies" }\end{array}$ & 15 & $44,12 \%$ & 19 & $55,88 \%$ \\
\hline $\begin{array}{l}\text { Enrichment of material needed in the subject "practicum } \\
\text { accounting for government institutions / agencies" }\end{array}$ & 33 & $97,06 \%$ & 1 & $2,94 \%$ \\
\hline $\begin{array}{l}\text { Has provided material enrichment in the subject "practicum } \\
\text { accounting for government institutions / agencies" }\end{array}$ & 4 & $11,76 \%$ & 30 & $88,24 \%$ \\
\hline $\begin{array}{l}\text { The material for preparing PPKD financial reports and } \\
\text { consolidating local government financial reports can be used as } \\
\text { material enrichment in the subject of "government agency / } \\
\text { agency accounting practice" }\end{array}$ & 31 & $91,18 \%$ & 3 & $8,82 \%$ \\
\hline
\end{tabular}

The next question relates to readiness in teaching the subject of "practicum accounting for government institutions / agencies". The third question asks whether participants already have books / references related to government accounting material, as many as 26 participants or $76.47 \%$ already have reference books related to government accounting topics while the remaining 8 participants $23.83 \%$ do not have reference 
books related to the topic government accounting. The fourth question asks whether the participants already have teaching materials for "accounting practicum for government institutions / agencies", as many as 15 participants or $44.12 \%$ already have teaching materials for the practical subjects of accounting for government institutions / agencies while 19 participants or $55.88 \%$ do not have teaching materials for practical subjects in accounting for government agencies / agencies.

The fifth question asks whether the participants need material enrichment in the subject "accounting practicum for government institutions / agencies", as many as 33 participants or $97.06 \%$ need material enrichment in the subject of practical accounting for government institutions / agencies. While the remaining 1 participant or $2.97 \%$ does not requires enrichment of material in the subject of practical accounting for institutions / government agencies. The sixth question asks whether the participants have provided material enrichment in "accounting practicum for government institutions / agencies" as many as 4 participants or
$11.76 \%$ have provided enrichment material in the subject "accounting practicum for government institutions / agencies", while the remaining 30 people or $88.24 \%$ has not provided material enrichment in the subject of practical accounting for government institutions / agencies.

The seventh question asks whether the material for PPKD financial report preparation and regional government financial statement consolidation can be used as material enrichment in the subject "accounting practicum for government institutions / agencies", as many as 31 participants or $91.18 \%$ can make PPKD financial report preparation materials and consolidated government financial statements. regions for material enrichment in the subject of practical accounting for government institutions / agencies, while the remaining 3 people or $8.82 \%$ cannot make PPKD financial report preparation materials and regional government financial report consolidation for material enrichment in the subject of practical accounting for government institutions / agencies.

Table 3. Tests of Normality

\begin{tabular}{|l|r|r|r|r|r|r|}
\hline & \multicolumn{4}{|c|}{ Kolmogorov-Smirnov ${ }^{\text {a }}$} & \multicolumn{3}{c|}{ Shapiro-Wilk } \\
\cline { 2 - 7 } & Statistic & Df & \multicolumn{1}{c|}{ Sig. } & \multicolumn{1}{c|}{ Statistic } & \multicolumn{1}{c|}{ Df } & \multicolumn{1}{c|}{ Sig. } \\
\hline Pre Test &, 131 & 32 &, 173 &, 954 & 32 &, 191 \\
\hline Post Test &, 194 & 32 &, 004 &, 942 & 32 &, 085 \\
\hline
\end{tabular}

a. Lilliefors Significance Correction

From the table test of normality can be shown that the pre-test and post-test data are normal. This can be seen from the significant level of Shapiro-Wilk, where the pre-test has a significant level of 0.191 , greater than 0.05 , which means that the pre-test data are normal, also for the post-test data, a significant level of Shapiro-Wilk is obtained of 0.085 , greater than 0.05 , which means the post-test data is also normally distributed.

Table 4. Test of Homogeneity of Variances

\begin{tabular}{|c|c|c|c|}
\hline Pre-test, Post-test \\
\hline Levene Statistic & df1 & df2 & Sig. \\
\hline 2,338 & 1 & 62 &, 131 \\
\hline
\end{tabular}

Based on the table above, it can be concluded that from the homogeneity test, a significant value of 0.131 is bigger than 0.05 , it means that all data in this study are the same and homogeneous.

Based on table, it is found that a significant level (2tailed) of 0.00 is smaller than 0.05 , which means that there is a significant difference between the pre-test and post-test. This result show that hypothesis of this research is accepted. The result prove that capacity building and workshop are alternative methods in order to enhance vocational teachers' understanding in government accounting which also automatically improve vocational teachers' professionalism in teaching government accounting.

Table 5. Independent Samples Test

\section{Independent Samples Test}

\begin{tabular}{|c|c|c|c|c|c|c|c|c|c|c|}
\hline & \multicolumn{2}{|c|}{ Levene's Test for } & \multicolumn{7}{|c|}{ t-test for Equality of Means } \\
\hline & & \multirow[b]{2}{*}{$\mathrm{F}$} & \multirow[b]{2}{*}{ Sig. } & \multirow[b]{2}{*}{$\mathrm{t}$} & \multirow[b]{2}{*}{$\mathrm{df}$} & \multirow{2}{*}{$\begin{array}{l}\text { Sig. (2- } \\
\text { tailed) }\end{array}$} & \multirow{2}{*}{$\begin{array}{c}\text { Mean } \\
\text { Differenc }\end{array}$} & \multirow{2}{*}{$\begin{array}{l}\text { Std. } \\
\text { Error }\end{array}$} & \multicolumn{2}{|c|}{ 95\% Confidence } \\
\hline & & & & & & & & & Lower & Upper \\
\hline \multirow[t]{2}{*}{$\begin{array}{l}\text { Pre Test, } \\
\text { Post Test }\end{array}$} & $\begin{array}{l}\text { Equal variances } \\
\text { assumed }\end{array}$ & 2,338 &, 131 & $-15,574$ & 62 &, 000 & $-8,000$ &, 514 & $-9,027$ & $-6,973$ \\
\hline & $\begin{array}{l}\text { Equal variances } \\
\text { not assumed }\end{array}$ & & & $-15,574$ & 58,905 & 000 & $-8,000$ &, 514 & $-9,028$ & $-6,972$ \\
\hline
\end{tabular}




\section{CONCLUSIONS}

The results showed that there are differences on vocational accounting teachers' understanding about preparing local government financial statement for level head office and consolidation of local government financial statement before and after got capacity building and workshop. There are 3 limitations of this research are: a) number of participants which only 34 participants; b) only use multiple choices for pre-test and post-test; c) only use pre-experimental (nondesign). So, the reccomendations for future research are: a) future research can extend the number of participant; b) future research can create comprehensive case study as a tool for pre-test and post-test; b) subsequent research also can explore type of research experiments since this research only use pre-experimental (nondesign).

\section{ACKNOWLEDGMENTS}

We would like to thank you profusely to Faculty of Economics, Universitas Negeri Padang for giving us opportunity and financial support to complete this and other works.

\section{REFERENCES}

[1] M. U. Usman and S. Lilis, Upaya Optimalisasi Kegiatan Belajar Mengajar. Bandung: Remaja Rosdakarya, 1993.

[2] R. Bakar, "The influence of professional teachers on Padang vocational school students' achievement," Kasetsart J. Soc. Sci., 2018.

[3] B. L. Brown, "Vocational Teacher Professional Development Practice Application Berif No. 11," Eric Publication, 2000.

[4] H. Tanang and B. Abu, "Teacher Professionalism and Professional Development Practices in South Sulawesi, Indonesia," J. Curric. Teach., 2014. 